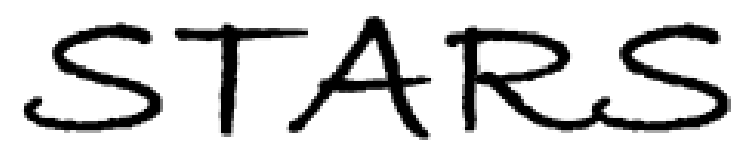

University of Central Florida

STARS

$1-1-2005$

\title{
Recreational boating activity and its impact on the recruitment and survival of the oyster Crassostrea virginica on intertidal reefs in Mosquito Lagoon, Florida
}

\author{
Lisa M. Wall \\ University of Central Florida \\ Linda J. Walters \\ University of Central Florida \\ Raymond E. Grizzle \\ Paul E. Sacks \\ University of Central Florida
}

Find similar works at: https://stars.library.ucf.edu/facultybib2000

University of Central Florida Libraries http://library.ucf.edu

This Article is brought to you for free and open access by the Faculty Bibliography at STARS. It has been accepted for inclusion in Faculty Bibliography 2000s by an authorized administrator of STARS. For more information, please contactSTARS@ucf.edu.

\section{Recommended Citation}

Wall, Lisa M.; Walters, Linda J.; Grizzle, Raymond E.; and Sacks, Paul E., "Recreational boating activity and its impact on the recruitment and survival of the oyster Crassostrea virginica on intertidal reefs in Mosquito Lagoon, Florida" (2005). Faculty Bibliography 2000s. 5748.

https://stars.library.ucf.edu/facultybib2000/5748

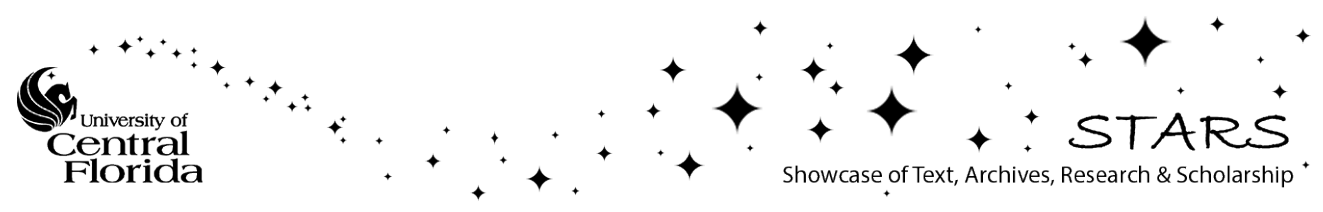




\section{BioOne COMPLETE}

\section{RECREATIONAL BOATING ACTIVITY AND ITS IMPACT ON THE RECRUITMENT AND SURVIVAL OF THE OYSTER CRASSOSTREA VIRGINICA ON INTERTIDAL REEFS IN MOSQUITO LAGOON, FLORIDA}

Authors: LISA M. WALL, LINDA J. WALTERS, RAYMOND E. GRIZZLE, and PAUL E. SACKS

Source: Journal of Shellfish Research, 24(4) : 965-973

Published By: National Shellfisheries Association

URL: https://doi.org/10.2983/0730-8000(2005)24[965:RBAAll]2.0.CO;2

BioOne Complete (complete.BioOne.org) is a full-text database of 200 subscribed and open-access titles in the biological, ecological, and environmental sciences published by nonprofit societies, associations, museums, institutions, and presses.

Your use of this PDF, the BioOne Complete website, and all posted and associated content indicates your acceptance of BioOne's Terms of Use, available at www.bioone.org/terms-of-use.

Usage of BioOne Complete content is strictly limited to personal, educational, and non-commercial use. Commercial inquiries or rights and permissions requests should be directed to the individual publisher as copyright holder.

BioOne sees sustainable scholarly publishing as an inherently collaborative enterprise connecting authors, nonprofit publishers, academic institutions, research libraries, and research funders in the common goal of maximizing access to critical research. 


\title{
RECREATIONAL BOATING ACTIVITY AND ITS IMPACT ON THE RECRUITMENT AND SURVIVAL OF THE OYSTER CRASSOSTREA VIRGINICA ON INTERTIDAL REEFS IN MOSQUITO LAGOON, FLORIDA
}

\author{
LISA M. WALL, ${ }^{1}$ LINDA J. WALTERS, ${ }^{1 *}$ RAYMOND E. GRIZZLE ${ }^{2}$ AND PAUL E. SACKS ${ }^{1,3}$ \\ ${ }^{1}$ Department of Biology, University of Central Florida, Orlando, Florida 32816; ${ }^{2}$ Jackson Estuarine \\ Laboratory, University of New Hampshire, Durham, New Hampshire 03824; ${ }^{3}$ Science Department, \\ Winter Springs High School, 130 Tuskawilla Road, Winter Springs, Florida 32708
}

\begin{abstract}
Along the east coast of central Florida in the Indian River Lagoon system, intense recreational boating activity occurs year-round, and intertidal reefs of the eastern oyster Crassostrea virginica (Gmelin) with dead margins (mounds of disarticulated shells) on their seaward edges are commonly found adjacent to major boating channels. These dead margins are caused, at least in part, by boat wakes and extend significantly higher above the high water line than reefs lacking dead margins (pristine reefs). To determine if these "impacted" oyster reefs alter recruitment and subsequent survival of $C$. virginica, three 8-wk field trials were run between May 2001 and April 2002 in Mosquito Lagoon. During each trial, data were also collected on total sediment loads, silt/clay fractions and relative water motion. Although recruitment did not differ between impacted and pristine reefs, juvenile survival was significantly reduced on impacted reefs. Additionally, larval recruitment and subsequent mortality were greatest during our summer trial. Total sediment loads, percent silt/clay, and relative water motion were significantly higher on impacted reefs. For these three variables, the largest values were consistently found at the bases of exposed (seaward) regions of impacted reefs. By documenting a positive relationship between reduced success of $C$. virginica and dead margins, and knowing that boat wakes contribute to the development of dead margins, we have provided the first cause and effect mechanism between intense recreational boating activity and increased oyster morality.
\end{abstract}

KEY WORDS: $\quad$ eastern oyster, larvae, Indian River Lagoon, boat wakes, Canaveral National Seashore, recreational boating, Crassostrea virginica

\section{INTRODUCTION}

Multiple anthropogenic environmental threats have encroached on estuarine systems in recent decades (e.g., Lenihan \& Peterson 1998, Breitburg et al. 1999, Coen et al. 1999a). In Florida, these problems include nutrient loading, creation of impoundments for mosquito eradication, large-scale channeling for flood control and commercial/recreational usage (Walters et al. 2001). Florida presently ranks second in the United States, behind Michigan, for number of registered recreational vessels (Harvey 2004). Although recreational boating in estuaries provides many benefits to society, our research suggests that recent increases in boating activity may be negatively impacting estuarine organisms.

In 1998, there were over 51,000 registered boats within the counties that border Mosquito Lagoon, the northernmost section of the Indian River Lagoon system along Florida's east coast (Grizzle et al. 2002). By 2003, there were 66,168 registered recreational vessels in these counties and an additional 6,653 personal watercraft (jet-skis) (Harvey 2004). This represents a $42.8 \%$ increase over 5 y. Some problems with the increase in the number of small vessels have been well documented. For example, increases in seagrass scarring from boat propellers and the number of marine mammal collisions are both positively correlated with increased boating activity (Provancha et al. 1992). However, little is known about the direct and indirect impacts of boating activity on other critical estuarine habitats in the landscape, such as intertidal reefs of the eastern oyster Crassostrea virginica.

Using aerial photographs taken between 1943 and 2000, Grizzle et al. (2002) described an increase in the number of uncharacteristic dead margins (mounds of disarticulated shells) rising up sharply from the seaward sides of intertidal oyster reefs in

\footnotetext{
*Corresponding author. E-mail: ljwalter@pegasus.cc.ucf.edu
}

major boating channels in Mosquito Lagoon. By the year 2000, 60 reefs $(15 \%)$ within the study area had dead margins. Calculated as total reef cover, this would represent $9.1 \%$ of the total oyster area. Many of these reefs were in narrow channels, making them less likely to be strongly affected by wind waves. Along the Intracoastal Waterway, a major navigation channel in the study area, some reefs had migrated away from the channel by as much as $50 \mathrm{~m}$ and consisted primarily of empty piles of sun-bleached shells extending as high as $1 \mathrm{~m}$ above the high tide mark (Grizzle et al. 2002), with terrestrial plants now established on them (L. Walters, pers. obs.). Oyster reefs in areas away from navigation channels showed little to no change over the 57-y study period (Grizzle et al. 2002).

Much of Mosquito Lagoon is under the jurisdiction of the National Park Service as Canaveral National Seashore. Canaveral National Seashore (CANA) was established in 1975 by Public Law 93-626 to preserve and protect the outstanding natural, scenic, scientific, ecologic and historic values of lands, shorelines and waters of this area and to provide public outdoor recreational use of these same waters. When recreational use negatively impacts one or more organisms, CANA resource managers must respond. Before this can happen, quantitative data are needed and the resource managers asked us to determine: (1) the causes of the dead margins and (2) if these margins negatively impact recruitment and survival of $C$. virginica. Elsewhere we will document how specific boat wake signatures can cause extensive shell movement and sediment resuspension (Walters et al. in prep.). Here we compare recruitment and post-settlement success of $C$. virginica on reefs with and without dead margins. We monitored recruitment, early juvenile survival, total sediment loads, percent silt/clay, relative water motion and the interactions between these variables on replicate intertidal oyster reefs within CANA. Throughout this article, oyster reefs in areas with intense boating activity and dead margins 
are referred to "impacted" reefs, whereas reefs with no dead margins and limited boating activity are referred to as "pristine" or "unimpacted" reefs.

\section{MATERIALS AND METHODS}

\section{Study Organism-the Eastern Oyster Crassostrea virginica}

The eastern oyster Crassostrea virginica occurs from the Gulf of the St. Lawrence in Canada to the Gulf of Mexico, in the Caribbean, and along the coasts of Brazil and Argentina (Carriker $\&$ Gaffney 1996). The southern-most geographic limit on the western Atlantic coast for expansive, intertidal oyster reefs of $C$. virginica is Mosquito Lagoon (Grizzle \& Castagna 1995). Growth, reproduction and survival of this broadcast spawner are greatest between $20^{\circ} \mathrm{C}$ to $30^{\circ} \mathrm{C}$ and at salinities between $15-30$ ppt (Shumway 1996). Thus, in central Florida, reproduction can occur yearround (Grizzle 1990). During external fertilization, gametogenesis is synchronized so that eggs and sperm are concurrently released to ensure fertilization and maximize zygote numbers (Thompson et al. 1996). Spawning is induced by environmental cues and the presence of gametes (Thompson et al.1996). Temperature and food supply affect the length of the larval period; planktotrophic oyster larvae may settle for up to 2 weeks after reaching the eyed-larval stage.

Larvae of Crassostrea virginica are photo-negative (e.g., Kennedy 1996) and respond to dissolved chemical cues by moving downward in the water column (Tamburri et al. 1992). Indeed, Baker (2003) found significantly more larvae near the benthos than the rest of the water column during repeated field sampling. The stimuli are peptides released into the water column by adult conspecifics (Zimmer-Faust \& Tamburri 1994). These waterborne chemicals evoked settlement behavior in still and flowing water (Turner et al. 1994, Tamburri et al. 1996). Next, if appropriate stimuli are contacted, the larva cements its left valve to the substrate and metamorphoses. At this stage, it is called a spat.

Settlement is a one-time event and larvae prefer hard, unfouled, sediment-free surfaces (e.g., MacKenzie 1977, MacKenzie 1983, Ortega \& Sutherland 1992). Nelson (1953), and Ortega \& Sutherland (1992) reported that most oyster larvae settled on the undersurfaces of experimental shells in the field, thereby avoiding sedimentation. Additionally, Gunter (1979) found that oyster beds covered with a layer of sediment several centimeters thick reduced oyster settlement. This field study compared Mississippi oyster reefs where predation, in concert with high sediment/silt levels, may have contributed to low recruitment. Gunter (1979) hypothesized that the settling larvae were killed by abrasion.

\section{Study Location and Reef Topographies}

The average depth of Mosquito Lagoon is less than $1 \mathrm{~m}$ and the current is primarily wind-driven (Walters et al. 2001), although tidal currents are important in some locations (R. Grizzle, pers. obs.). Annual salinity ranges between 25 and $45 \mathrm{ppt}$, depending on rainfall (Walters et al. 2001). Intertidal reefs of $C$. virginica are a dominant habitat type in Mosquito Lagoon and individual reefs range in size from a few $\mathrm{m}^{2}$ to approximately $6,000 \mathrm{~m}^{2}$ (Grizzle 1990). Beds of the seagrass Halodule wrightii often are located on the seaward edges of these oyster reefs, whereas the cordgrass Spartina alterniflora or mangrove communities bound their landward edges (Morris et al. 2000, Grizzle et al. 2002). In CANA, limited commercial and recreational harvesting continues (Walters et al. 2001).

Eight oyster reefs were chosen for this study; four impacted reefs had significant dead margins and four reefs were in pristine condition. Profiles of each reef (Fig. 1) were created by measuring reef elevation at increments of $20 \mathrm{~cm}$ from the landward to seaward edges of each reef with a laser level (Johnson 9100/40-0909) secured to a tripod, a tape measure and a stadia rod. All measurements were adjusted to mean low water. To minimize observer bias, the location of each reef profile was set to hit the highest point on each reef. Maximum differences in elevation (mean $\pm \mathrm{SE}$; impacted reefs: $53.63 \pm 3.98 \mathrm{~cm}$; pristine reefs: $28.63 \pm 2.29 \mathrm{~cm}$ ) were significantly different when compared with a 1-way ANOVA (F $=29.60, P=0.0016)$ (Fig. 1).

\section{Recruitment and Survival of C. virginica}

Recruitment and survival were monitored over 12 mo during three 8-wk trials. The first trial began on May 6, 2001. The second began on December 15, 2001 and the third trial began on March 6, 2002. For each trial, twenty-four $0.25 \mathrm{~m}^{2}$ frames were constructed from $1.9 \mathrm{~cm}$ PVC pipe and black plastic mesh (Vexar: $1.0-\mathrm{cm}$ opening) that was attached to the PVC with cable ties (Ortega \& Sutherland 1992). Twenty-five, clean, randomly collected oyster
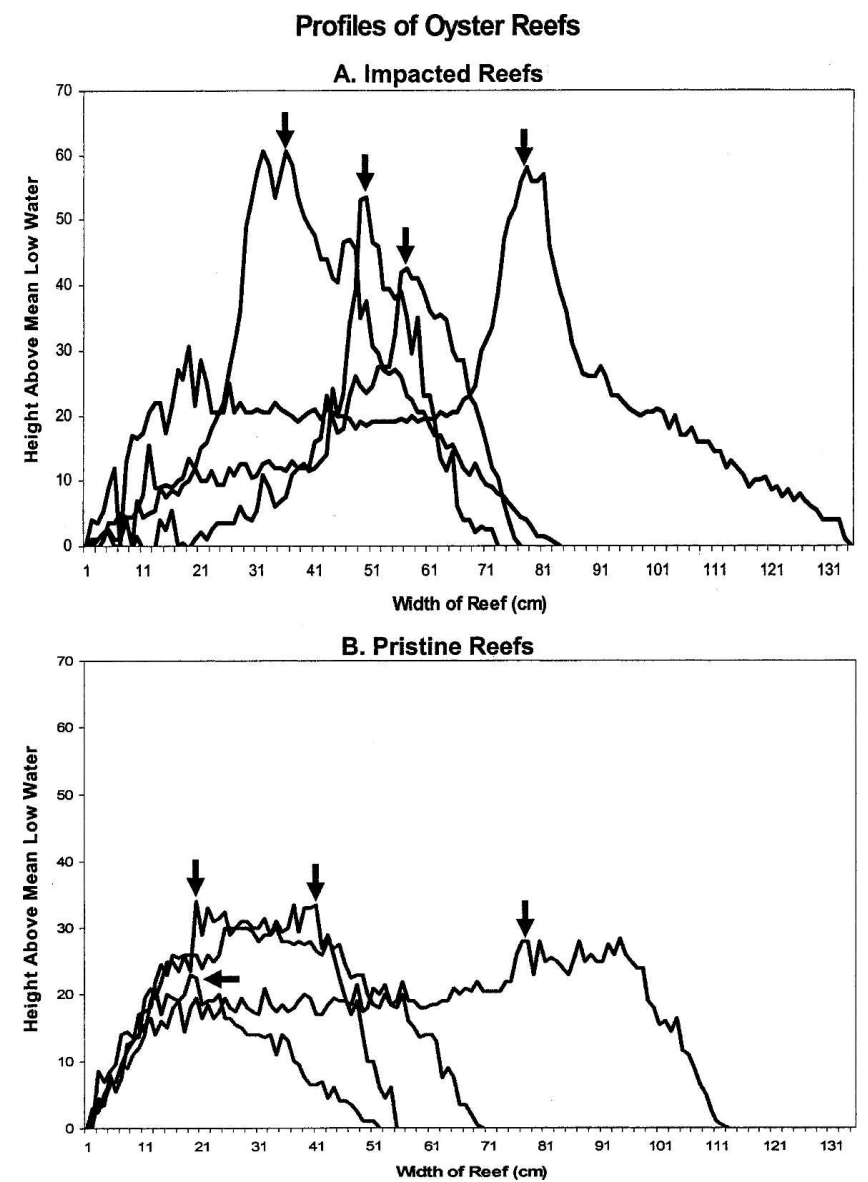

Figure 1. Profiles of 4 impacted reefs (A) and 4 pristine reefs (B) studied in Mosquito Lagoon. Data were collected at $20 \mathrm{~cm}$ intervals at mean low water from the landward $(0 \mathrm{~cm}$ on $\mathrm{x}$ axis) to seaward edge of each reef. Arrows show the highest point on each reef. All measurements are in $\mathbf{c m}$. 
shells were drilled and attached with cable ties to the mesh of each frame in a $5 \times 5$ array. Half of the shells were attached with the inside of the valve facing the mesh. The remaining shells had the inside of the valve exposed for recruitment. All recruitment mats were suspended, with shells facing downward, $15 \mathrm{~cm}$ above the bottom by cable ties and concrete blocks.

Recruitment and survival were monitored on the 4 impacted and 4 pristine reefs in 3 locations: (1) base of the seaward edge of each reef = "exposed" region; (2) the highest point on each reef (within the dead margin of impacted reefs, center of the pristine reefs) = "middle" region and (3) in the back-reef region of each reef $=$ "protected" region. Oyster recruitment and survival were monitored weekly using maps created from clear plastic transparencies and waterproof markers. We compared spat numbers per mat rather than per shell to account for individual differences in shell dimensions. In our analysis, an individual "survived" only if it remained on the substrate for a minimum of 4 weeks. Thus, survival was only analyzed for individuals that settled during weeks $1-4$

\section{Sediment Loads}

Sediment loads were monitored weekly using replicate, cylindrical PVC pipe sediment traps $(10 \mathrm{~cm}$ diameter $\times 25 \mathrm{~cm}$ deep) submerged flush with the substrate (methods: Lenihan 1999). One trap was placed $1.5 \mathrm{~m}$ from each recruitment mat at each location on each reef. Traps were capped underwater and retrieved every 7 days. New, replacement traps were immediately deployed. Total sediment was determined by drying samples at $60^{\circ} \mathrm{C}$ for $3 \mathrm{~d}$ in a drying oven (Econotherm 51,221,126) and weighing the contents on a top loading balance (O'Haus Scout SC6010). Percent silt/clay (particles $<62 \mu \mathrm{m}$ ) was determined by grinding dried sediment with a mortar and pestle and sorting samples with a $0.062 \mathrm{~mm}$ sieve (Levinton 2001).

\section{Relative Water Motion}

Relative water motion was measured by the dissolution of replicate calcium sulfate (plaster-of-Paris) spheres (e.g., Muus 1968, Doty 1971, Thompson \& Glenn 1994). This provided a relative measure that incorporated tidal currents, wind-generated waves and boat wakes. To create the spheres, plaster-of-Paris (Botanicals Art and Science) was poured into 5-cm diameter round candle molds (Candle Crafting Molds, 110,791). A 15-cm long metal rod was placed in each mold; whereas the plaster was setting to create a narrow diameter hole through the center into which a cable tie was later inserted. Spheres were dried at $60^{\circ} \mathrm{C}$ for $24 \mathrm{~h}$ prior to start of each trial in a drying oven and weighed on a top-loading balance.

Spheres were deployed at the exposed, middle and protected areas on 2 impacted and 2 pristine reefs. All were attached to concrete blocks with cable ties so they were $15 \mathrm{~cm}$ off the bottom. At each 1-wk sampling interval, the plaster spheres were removed and replaced with new ones. Collected spheres were dried and reweighed to determine weight loss (described earlier).

\section{Statistical Analyses}

Three-way, repeated measure analysis of variance (ANOVA) models were used to determine differences in: (1) recruitment, (2) percent survival, (3) total sediment loads, (4) percent silt/clay and (5) relative water motion. Factors in each ANOVA were: reef type (impacted, pristine), location on reef (exposed, middle, protected) and season (summer, winter, spring). To test for normality and heterogeneity, Levene $\mathrm{F}$ and Kolmagorov-Smirnov tests were run. A posteriori Bonferroni pairwise comparisons were used to determine differences among the treatments with the level of significance at $\alpha=0.05$ with $95 \%$ confidence intervals.

\section{RESULTS}

\section{Recruitment}

Although recruitment has been documented to occur yearround in Mosquito Lagoon (Grizzle \& Castagna 1995), no recruitment occurred during our winter 2001-2002 trial, so it was not included in this analysis. For the summer and spring trials, mean recruitment did not differ between impacted and pristine reefs $(P=0.6712$; Table 1; Fig. 2A). Recruitment was, however, significantly higher during the summer 2001 trial than the spring 2002 trial $(P=0.0302$; Fig. 2A). Recruitment also differed significantly within reef locations for both seasons $(P<0.0001)$; the exposed and protected regions had significantly higher recruitment than the middle regions (Fig. 2B).

\section{Percent Survival}

Mean percent survival differed significantly for reef type, location within reef, season and the interaction between reef type and season (Table 2). Survival was significantly lower on impacted reefs $(P<0.0001$; Fig. $3 \mathrm{~A})$ and during the summer $(P=0.0001$; Fig. 3A). Exposed and protected regions of each reef type had higher percent survival than the middle regions $(P=0.0032$; Fig. 3B).

\section{Sediment Loads}

Total sediment loads were significantly higher on impacted reefs than pristine reefs $(P=0.0500$; Table 3$)$. Additionally, on impacted reefs, the exposed regions had the largest sediment loads, protected regions had intermediate loads, and the middle regions had the smallest loads (exposed $>$ protected $>$ middle; $P<0.0001$; Fig. 4A to C). In contrast, on pristine reefs, the exposed regions and protected regions experienced similar sediment loads, with the middle regions receiving less (exposed $=$ protected $>$ middle; $P<$ 0.0001; Fig. 4A to C). Compared seasonally, sediment loads were significantly higher during the summer 2001 trial than in winter

TABLE 1.

Recruitment of $C$. virginica. Results of 3-way ANOVA with reef type (impacted, unimpacted $=$ pristine), location on reef (exposed, middle, protected) and season (summer 2001, spring 2002) as main factors.

\begin{tabular}{lccrr}
\hline \hline \multicolumn{1}{c}{ Source } & df & Mean Square & \multicolumn{1}{c}{$\boldsymbol{F}$} & \multicolumn{1}{c}{$\boldsymbol{P}$} \\
\hline Reef type (T) & 1 & 588.0 & 0.18 & 0.6712 \\
Location on reef (L) & 2 & 6547.5 & 20.55 & $<0.0001$ \\
Season (S) & 1 & 16354.0 & 5.10 & 0.0302 \\
$\mathrm{~T} \times \mathrm{L}$ & 2 & 1469.8 & 0.46 & 0.6362 \\
$\mathrm{~T} \times \mathrm{S}$ & 1 & 1656.8 & 0.52 & 0.4771 \\
$\mathrm{~L} \times \mathrm{S}$ & 2 & 10343.5 & 3.22 & 0.0516 \\
$\mathrm{~T} \times \mathrm{L} \times \mathrm{S}$ & 2 & 1110.4 & 0.35 & 0.7099 \\
\hline
\end{tabular}


A. Oyster Recruitment by Reef Type and Season

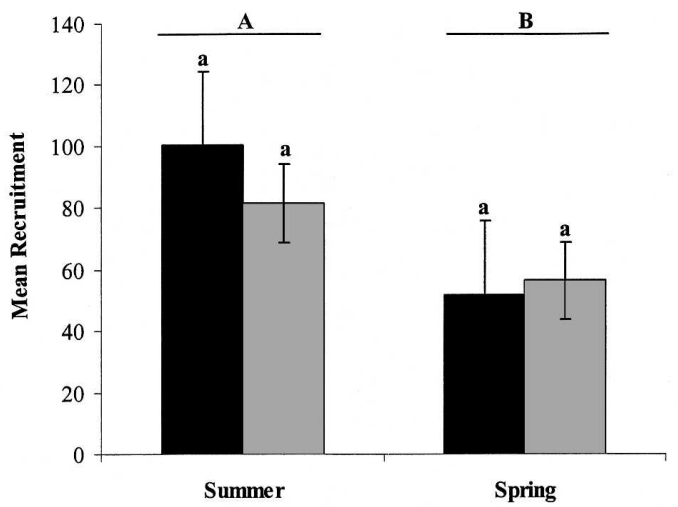

B. Oyster Recruitment by Location and Season

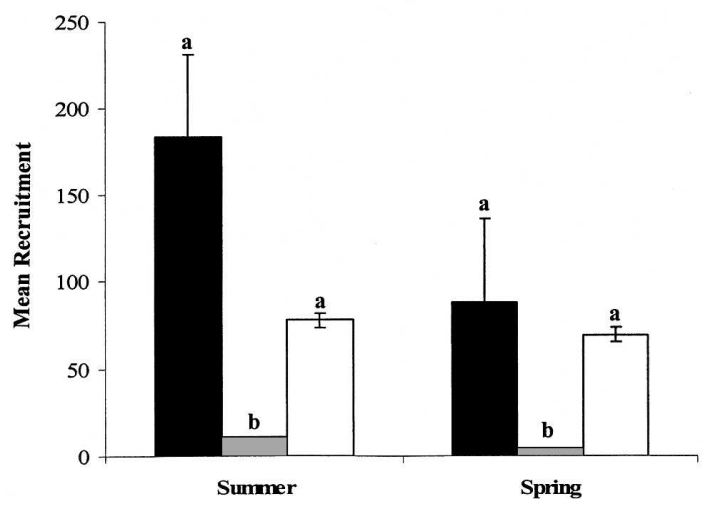

Figure 2. Mean oyster recruitment $( \pm \mathrm{SE})$ on impacted and pristine reefs during summer 2001 and spring 2002 trials by reef type (A) and location on reefs $(B)$. Letters represent means that are significantly different. Capital letters refer to seasonal differences, lower case letters refer to differences between reef type (impacted vs. unimpacted $=$ pristine) at the $\boldsymbol{P} \leq \mathbf{0 . 0 5}$ level when compared with Bonferroni's pairwise comparisons.

and spring trials (Fig. 4A to C). Sediment loads were similar during the winter and spring trials.

\section{Percent Silt/Clay}

Percent silt/clay differed significantly between impacted and pristine reefs, with greater percent silt/clay on impacted reefs $(P=0.0139$; Table 4; Fig. 5A to $\mathrm{C})$. Percent silt/clay was similar

TABLE 2.

Mean percent survival of $C$. virginica. Results of a 3-way ANOVA with reef type (impacted, pristine), location on reef (exposed, middle, protected), and season (summer 2001, spring 2002) as main factors.

\begin{tabular}{lccrr}
\hline \hline \multicolumn{1}{c}{ Source } & df & Mean Square & \multicolumn{1}{c}{$\boldsymbol{F}$} & \multicolumn{1}{c}{$\boldsymbol{P}$} \\
\hline Reef type (T) & 1 & 12875.66 & 52.48 & $<0.0001$ \\
Location on reef (L) & 2 & 1662.44 & 6.78 & 0.0032 \\
Season (S) & 1 & 4570.97 & 18.63 & 0.0001 \\
$\mathrm{~T} \times \mathrm{L}$ & 2 & 354.78 & 1.45 & 0.2488 \\
$\mathrm{~T} \times \mathrm{S}$ & 1 & 4420.07 & 18.02 & 0.0001 \\
$\mathrm{~L} \times \mathrm{S}$ & 2 & 24.77 & 0.10 & 0.9042 \\
$\mathrm{~T} \times \mathrm{L} \times \mathrm{S}$ & 2 & 97.04 & 0.40 & 0.6762 \\
\hline
\end{tabular}

A. Mean Percent Survival by Reef Type and Season

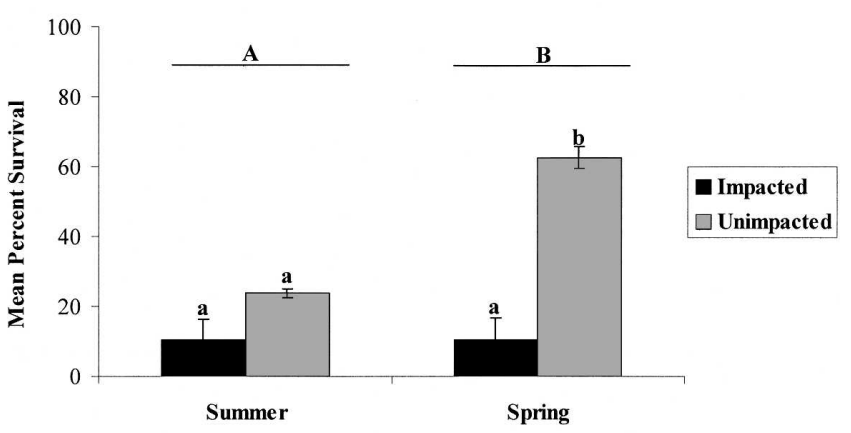

B. Mean Percent Survival by Location and Season

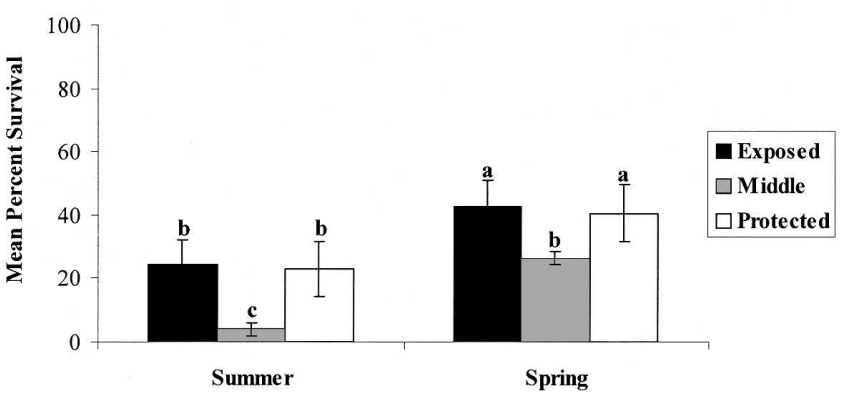

Figure 3. Percent oyster survival $( \pm S E)$ for the summer and spring trials on impacted and pristine reefs (A) and by location on reefs (B). Letters represent means that are significantly different. Capital letters refer to seasonal differences, lower case letters refer to differences between reef type (impacted vs. unimpacted) at the $\boldsymbol{P} \leq 0.05$ level when compared with Bonferroni's pairwise comparisons.

among seasons even though total sediment loads were much greater during the summer trial than in the winter and spring $(P=$ $0.4321)$. Percent silt/clay differed significantly within reef locations $(P=0.0025$; Fig. 5A-C). There were also significant interactions for reef type $\mathrm{X}$ location on reef and for reef type $\mathrm{X}$ season (Table 4).

\section{Relative Water Motion}

Dissolution rates of plaster-of-Paris spheres differed between reef types during all seasons, with impacted reefs receiving significantly greater flow rates than pristine reefs $(P<0.0001$; Table 5). Dissolution rates also differed significantly within reef locations $(P<0.0001)$; exposed regions experienced greater rela-

\section{TABLE 3.}

Sediment loads. Results of a 3-way ANOVA with reef type (inpacted, pristine), location on reef (exposed, middle, protected), and season (summer 2001, winter 2001-2002; spring 2002) as the main factors.

\begin{tabular}{lccrr}
\hline \hline \multicolumn{1}{c}{ Source } & df & Mean square & \multicolumn{1}{c}{$\boldsymbol{F}$} & \multicolumn{1}{c}{$\boldsymbol{P}$} \\
\hline Reef type (T) & 1 & 740.38 & 4.02 & 0.0500 \\
Location on reef (L) & 2 & 6195.40 & 33.64 & $<0.0001$ \\
Season (S) & 2 & 1726.69 & 9.38 & 0.0003 \\
$\mathrm{~T} \times \mathrm{L}$ & 2 & 1062.91 & 5.77 & 0.0540 \\
$\mathrm{~T} \times \mathrm{S}$ & 1 & 120.35 & 0.65 & 0.5243 \\
$\mathrm{~L} \times \mathrm{S}$ & 4 & 182.07 & 0.99 & 0.4216 \\
$\mathrm{~T} \times \mathrm{L} \times \mathrm{S}$ & 4 & 75.57 & 0.41 & 0.8004 \\
\hline
\end{tabular}


A.

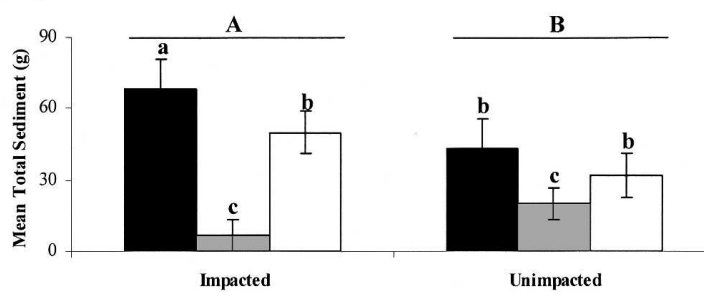

B. Mean Total Sediment: Winter 2001-2002

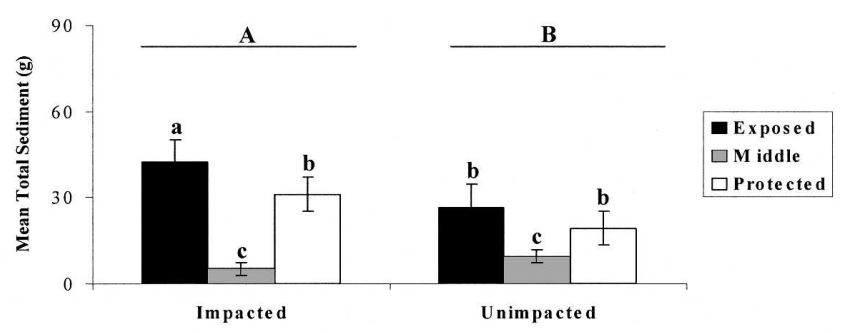

C.

Mean Total Sediment: Spring 2002

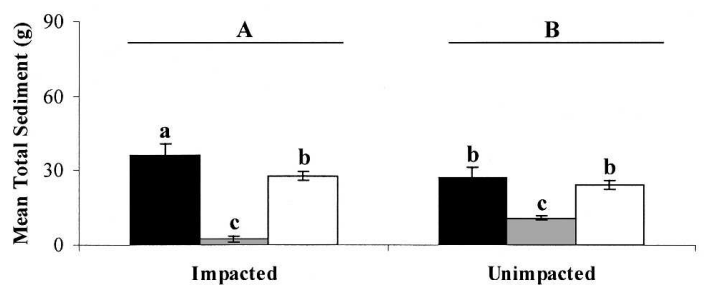

Figure 4. Mean total sediment load $( \pm$ SE) during the summer (A), winter (B) and spring (C) trials on the exposed, middle, and protected regions of impacted and unimpacted reefs. Capital letters represent means that are significantly different between reef types. Lower case letters represent means that are significantly different within reef locations at the $\boldsymbol{P} \leq \boldsymbol{0 . 0 5}$ level when compared with Bonferroni's pairwise comparisons.

tive water motion than the protected or middle regions (Table 5; Fig. 6A to C). Dissolution rates were significantly higher during the summer 2001 trial, whereas similar for winter and spring $(P=$ 0.0291; Fig. 6A to C). A significant interaction was also identified for reef type $\mathrm{X}$ location on reef (Table 5).

\section{DISCUSSION}

In Mosquito Lagoon, there was a 9\% annual increase in bottom area covered by dead margins on the seaward edges of intertidal

TABLE 4.

Percent silt/clay in sediment loads. Results of 3-way ANOVA with reef type (impacted, pristine), location on reef (exposed, middle, protected), and season (summer 2001, winter 2001-2002; spring 2002) as the main factors.

\begin{tabular}{lcccc}
\hline \hline \multicolumn{1}{c}{ Source } & df & Mean Square & $\boldsymbol{F}$ & $\boldsymbol{P}$ \\
\hline Reef type (T) & 1 & 258.42 & 6.46 & 0.0139 \\
Location on reef (L) & 2 & 268.19 & 6.71 & 0.0025 \\
Season (S) & 2 & 34.09 & 0.85 & 0.4321 \\
$\mathrm{~T} \times \mathrm{L}$ & 2 & 264.85 & 6.62 & 0.0027 \\
$\mathrm{~T} \times \mathrm{S}$ & 1 & 287.50 & 7.19 & 0.0017 \\
$\mathrm{~L} \times \mathrm{S}$ & 4 & 61.66 & 1.54 & 0.2032 \\
$\mathrm{~T} \times \mathrm{L} \times \mathrm{S}$ & 4 & 70.18 & 1.75 & 0.1515 \\
\hline
\end{tabular}

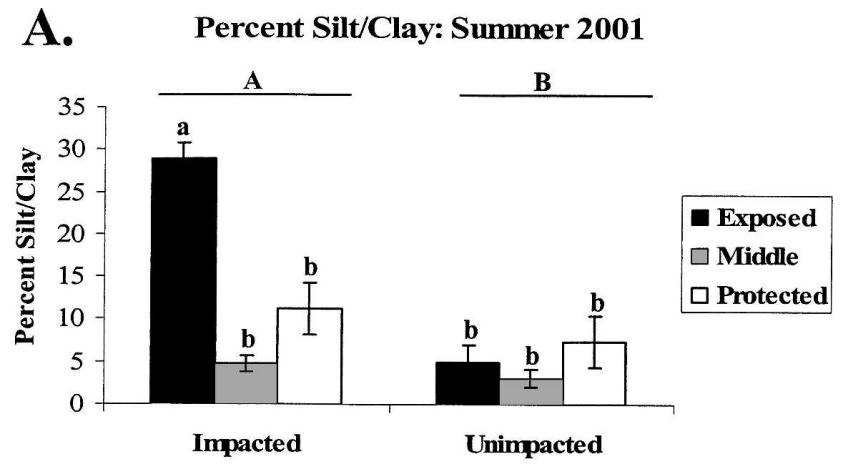

\section{B. Percent Silt/Clay: Winter 2001-2002}

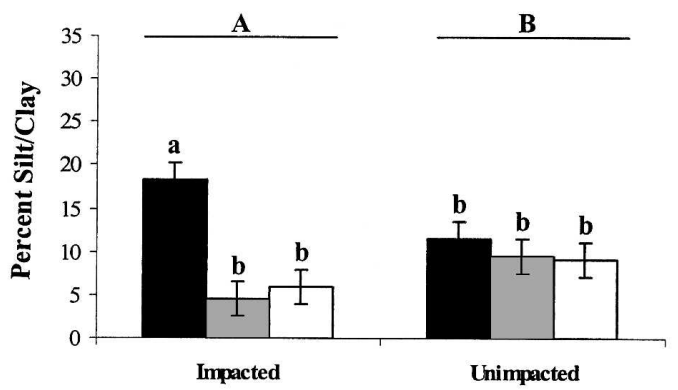

Exposed

$\square$ Middle

$\square$ Protected

Percent Silt/Clay: Spring 2002
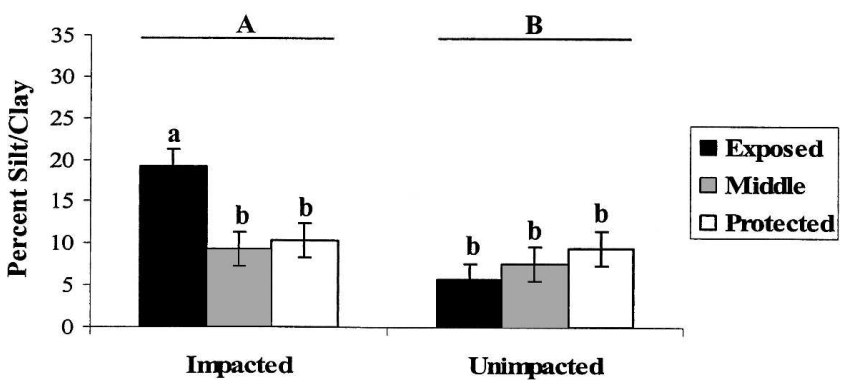

Figure 5. Percent silt/clay ( \pm SE) during the summer (A), winter (B) and spring $(\mathrm{C})$ trials on the exposed, middle, and protected regions of impacted and unimpacted reefs. Capital letters represent means that are significantly different between reef types. Lower case letters represent means that are significantly different within reef locations at the $P \leq \mathbf{0 . 0 5}$ level when compared with Bonferroni's pairwise comparisons.

reefs of the oyster $C$. virginica between 1988 and 1995 (Grizzle et al. 2002). During the same period, a $10 \%$ average annual increase in the number of boats registered was documented for the 2 counties, Brevard and Volusia, which surround Mosquito Lagoon (Hart et al. 1994). During the next period examined (1995-2000), the extent of dead margins increased by $16.4 \%$ (Grizzle et al. 2002). This increase in the creation of dead margins does not show any signs of stopping (L. Walters, pers. obs.). New dead margins continue to appear in these waters on a regular basis. In fact, 1 year after this study was completed, one of the "pristine" reefs began to show signs of dead margin formation. Boating activity in waters surrounding this reef increased at the same time as it became widely known as a prime fishing spot (L. Walters, pers. obs.).

Kennish and Orth (Kennish 2002a) convened a workshop in November 2000 to discuss the known diversity of impacts of motorized boats on shallow water systems and to develop management suggestions for coastal resource managers faced with the 
TABLE 5.

Plaster-of Paris dissolution rates as a proxy for relative water motion. Results of a 3-way ANOVA with reef type (impacted, pristine), location on reef (exposed, middle, protected), and season (summer 2001, winter 2001-2002; spring 2002) as main factors.

\begin{tabular}{lcrrr}
\hline \hline \multicolumn{1}{c}{ Source } & df & Mean Square & \multicolumn{1}{c}{$\boldsymbol{F}$} & \multicolumn{1}{c}{$\boldsymbol{P}$} \\
\hline Reef type (T) & 1 & 6679.59 & 33.79 & $<0.0001$ \\
Location on reef (L) & 2 & 48695.22 & 246.35 & $<0.0001$ \\
Season (S) & 2 & 856.74 & 4.33 & 0.0291 \\
$\mathrm{~T} \times \mathrm{L}$ & 2 & 5241.32 & 26.52 & $<0.0001$ \\
$\mathrm{~T} \times \mathrm{S}$ & 2 & 292.59 & 1.48 & 0.2540 \\
$\mathrm{~L} \times \mathrm{S}$ & 4 & 330.63 & 1.67 & 0.2000 \\
$\mathrm{~T} \times \mathrm{L} \times \mathrm{S}$ & 4 & 125.97 & 0.64 & 0.6426 \\
\hline
\end{tabular}

ever-increasing numbers of recreational motorized watercraft on their waterways. They focused on jet and propeller-driven boats $<6 \mathrm{~m}$ in length and personal watercraft (i.e., jet skis) $<5 \mathrm{~m}$ long. Topics included: boats directly or indirectly causing long-term scarring of submerged aquatic vegetation (Dunton \& Schonberg 2002, Kenworthy et al. 2002, Koch 2002, Whitfield et al. 2002) impacts of boat noise on nesting birds (Burger 2002) and propeller-induced sediment resuspension and its associated role in releasing contaminants from benthic sediments (Ailstock et al. 2002, Albers 2002, Anderson 2002, Crawford 2002, Kennish 2002b). This research documents another impact of vessels in this size category: reducing spat survival of the ecologically and economically important eastern oyster $C$. virginica.

\section{Influence of Abiotic Variables on Oyster Success}

Three important abiotic variables, water motion, total sediment load and silt-clay fraction were all highest along the exposed seaward edges of impacted reefs. These results were not surprising. The bases of the steep slopes of the impacted reefs created ideal depositional environments (Fig. 1). In contrast, the highest regions of the impacted reefs (middle region) rarely, if ever, were submerged and thus collected little or no sediment. Any larvae that settled or were attached to shells transported this location by wakes likely died of exposure. Although the middle regions of pristine reefs also had reduced water flow, they were submerged on a daily basis (L. Wall, pers. obs.).

Higher levels of water motion at the bases of impacted reefs could influence spat survival in several ways. A direct impact could be enhanced water motion causing live oysters or disarticulated shells to be dislodged after spat attached to them. If this occurs, then spat could be damaged as the spat and its substrate tumbled over the benthos (Walters et al. 2002, in prep.). Alternatively, a spat may survive the tumbling if it settled in a crevice, but then die of starvation or exposure if it ends up on top of a dead margin. Substrate dislodgement was not an issue in our trials because of the design of recruitment mats. All shells were secured to frames throughout each trial.

Lenihan (1999) found that recruitment of $C$. virginica did not vary with flow rate on subtidal reefs in the Neuse River Estuary, North Carolina. On these reefs, however, mortality was greatest in the low flow $(<4 \mathrm{~cm} / \mathrm{s})$ areas at the bases of these subtidal reefs; oysters fared significantly better near the reef crests where flows ranged from 7-20 cm/s (Lenihan 1999, Lenihan et al. 1999). O'Beirn et al. (1995) found that oyster recruitment decreased with wave exposure on subtidal oyster reefs in Georgia, whereas Bahr and Lanier (1981) suggest that water movement above a certain threshold level will inhibit reef development. In our study, recruitment did not vary with reef type (impacted vs. pristine), but did vary with location on reefs. Indeed, Figure 2B and Figures 6A to $\mathrm{C}$ depict that recruitment and relative water motion by location on reefs look similar. The lack of difference between reef types may be explained by the overall low flow rates in this system (main stream flow average: $5 \mathrm{~cm} / \mathrm{s}$; Walters et al. 2001). Increased settlement on exposed regions of reefs does agree with studies by Mullineaux and Garland (1993) and Sandford et al. (1994) who found larval recruitment to be greatest where flow rates were faster because of enhanced larval supply.

Water motion may also bring with it other larval forms that may compete for space with oyster spat and potential oyster parasites. Ortega \& Sutherland (1992) documented that oyster shells became much less desirable for conspecific larvae if various flora

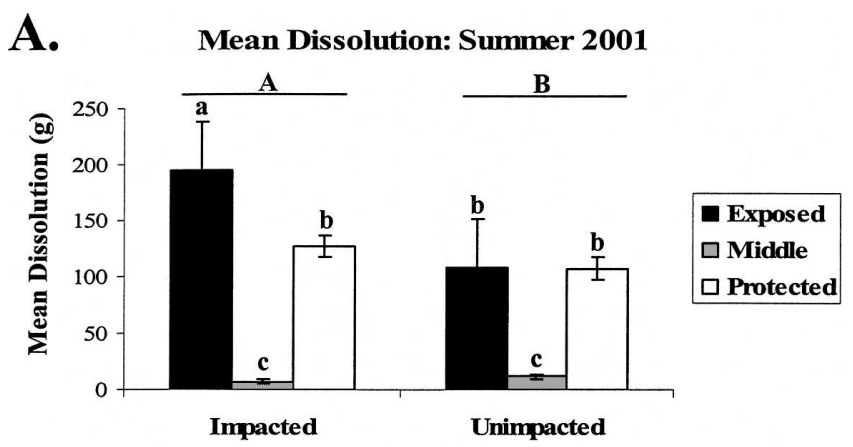

B. Mean Dissolution: Winter 2001-2002

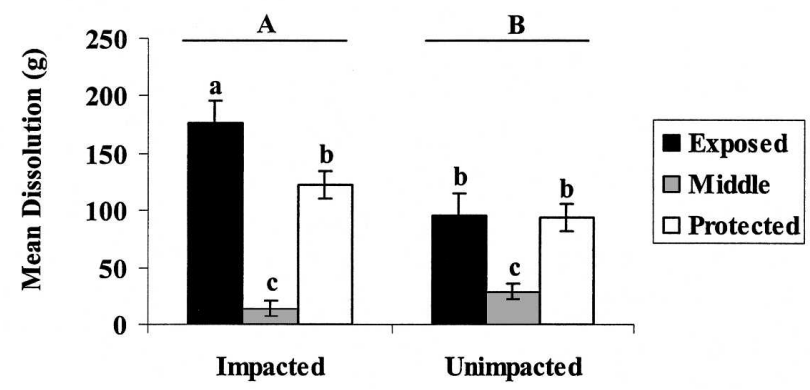

C. Mean Dissolution: Spring 2002

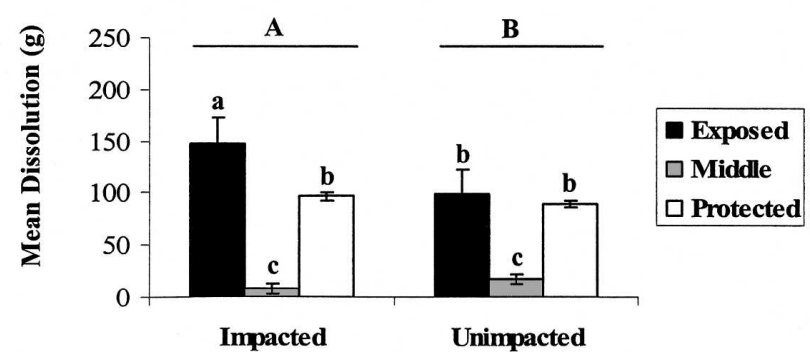

Figure 6. Mean dissolution of plaster spheres $( \pm \mathrm{SE})$ used to determine relative water motion during the summer $(A)$, winter $(B)$ and spring (C) trials on the exposed, middle and protected regions of impacted and unimpacted reefs. Capital letters represent means that are significantly different between reef types. Lower case letters represent means that are significantly different within reef locations at the $P \leq 0.05$ level when compared with Bonferroni's pairwise comparisons. 
and fauna have already attached to the shells when compared with clean shells deployed for the same period. For larvae of $C$. virginica that did not become prey to solitary ascidians, Osman et al. (1989) also found that post-settlement success was strongly affected by the presence of sessile species. They found that encrusting bryozoans and ascidians completely overgrew juvenile oysters, whereas other sessile species reduced subsequent oyster growth. The number of potential spatial competitors was small in our spring trial. Mortality was enhanced during our summer trial in part because of interference competition with native and invasive barnacles. In the summer, over 300 barnacles (Balanus eburneus and $B$. amphitrite) were counted on many shells on our recruitment mats (Wall 2004). Both barnacle species were found to settle on top of oyster spat that prevented the oysters from feeding and to settle adjacent to spat, eventually dislodging them by growing under their edges (L. Walters, pers. obs.).

Lenihan et al. (1999) refuted the idea that enhanced water motion on subtidal reefs resulted in higher levels of the protozoan Perkinsus marinus. In their trials, Perkinsus infection was greatest at the bases of reefs where flow was slowest and oysters experienced the most physiologic stress. In Mosquito Lagoon, Perkensis levels were uniformly low and unlikely to have created the differences found between impacted and pristine reefs (Walters et al. in prep.). These differences highlight some important distinctions between subtidal reefs studied by Lenihan (1999) and intertidal reefs (this study) and warn scientists and managers to exercise caution when making generalizations about species that reside in both habitats.

During all our trials, low oyster survival was positively correlated with high sediment loads and high silt/clay levels in the sediment. Many authors (e.g., Marshall 1954, MacKenzie 1977; 1983; 1996, Gunter 1979, Lenihan 1999, Perret et al. 1999) have found increased sediment loads reduced oyster survival and thus reef development. MacKenzie (1996) hypothesized that an increase in sediment load killed settled larvae by abrasion. Similar results have been results found for many other marine species on reefs and rocky habitats (e.g., Loya 1976, Konar \& Roberts 1996).

\section{Restoration Implications}

No one debates the economic importance of $C$. virginica. Now there is a preponderance of data documenting the important ecologic services provided by this species (e.g., Coen et al. 1999a; 1999b, Breitburg et al. 2000). Research on C. virginica has been and continues to be used to guide restoration efforts at local and regional levels (e.g., Bartol et al. 1999, Luckenbach et al. 1999, Whitlatch \& Osman 1999, Coen \& Luckenbach 2000). In Mosquito Lagoon, we identified seasonal differences in recruitment, percent survival, sediment loads and relative water motion (Tables 1-5). Because local restoration efforts should coincide with peak larval abundances, restoration should occur in spring months in Mosquito Lagoon. Spring was also the season with lowest sediment loads, lowest relative water motion and highest survival. To maximize spat set, materials for spat collection (disarticulated shells, reef balls, etc.) should be deployed on the exposed regions of pristine reefs, where oyster recruitment was high and sediment loads and water flow were low. Finally, because substrate retention is critical for juvenile survival, the recruitment substrate must be deployed in a manner that it will remain in place. In past unsuccessful attempts to restore oyster reefs, piles of shells or other material were deployed with little attention given to the physical structure of the habitat being created or where on these structures oyster success would be maximized.

The motivations for this study were to: (1) determine seasonal differences in recruitment and survival of $C$. virginica on impacted versus pristine reefs and (2) collect data on abiotic variables that might help explain any differences between reef types and potentially improve restoration protocols. Crassostrea virginica did poorly on the seaward edges of impacted reefs; relative water motion, sediment loads and percent silt/clay were all high in this location. This research provides the first direct link between increased mortality of $C$. virginica and the presence of dead margins and the first potential connection between the decline of this species and recreational boating activity.

\section{ACKNOWLEDGMENTS}

The authors thank J. Sacks, D. Campeau, K. Johnson, N. Martinez, E. Flores, M. Abgrall, N. Robinson, J. Grevert, J. Stiner, M. Boudreaux, C. Glardon, A. Simpson and J. Liss, for assistance in the field and lab; Superintendent R. Newkirk and Resource Managers J. Stiner and D. Mock, who provided access to this wonderful habitat and much in-kind support; L. Coen, for his oyster expertise and L. Hoffman, for assistance with data analysis. This work was supported by grants from Florida Sea Grant (R/C-E-45), the National Park Service, and the University of Central Florida.

\section{LITERATURE CITED}

Ailstock, M. S., S. G. Horner, C. M. Norman \& E. M. Davids. 2002. Resuspension of sediments by watercraft operated in shallow water habitats of Anne Arundel County, Maryland. In: M. J. Kennish, editor. Impacts of motorized watercraft on shallow estuarine and coastal marine environments. J. Coastal Res. (special issue). 37:18-32.

Albers, P. H. 2002. Sources, fate, and effects of PAHs in shallow water environments: a review with special reference to small watercraft. In: M. J. Kennish, editor. Impacts of motorized watercraft on shallow estuarine and coastal marine environments. J. Coastal Res. (special issue). 37:143-152.

Anderson, F. E. 2002. Effect of wave-wash from personal watercraft on salt marsh channels. In: M. J. Kennish, editor. Impacts of motorized watercraft on shallow estuarine and coastal marine environments. J. Coastal Res. (special issue). 37:33-49.

Bahr, L. M. \& W. P. Lanier. 1981. The ecology of intertidal oyster reefs of the South Atlantic Coast: a community profile. US Fish Wildlife Services and Biological Service Program FWS/OBS/-81/15:105.
Baker, P. 2003. Two species of oyster larvae show different depth distributions in a shallow, well-mixed estuary. J. Shellfish Res. 22:733-736.

Bartol, I. K., R. Mann \& M. Luckenbach. 1999. Growth and mortality of oyster (Crassostrea virginica) on constructed intertidal reefs. J. Exp. Mar. Biol. Ecol. 237:157-184.

Breitburg, D. L., J. G. Sanders, C. C. Gilmore, C. A. Hatfield, R. W. Osman, G. F. Riedel, S. P. Seitziger \& K. G. Sellner. 1999. Variability in response to nutrients and trace elements, and transmission of stressor effects through an estuarine food web. Limnol. Oceanogr. 44:837-863.

Breitburg, D. L., L. D. Coen, M. W. Luckenbach, R. Mann, M. Posey \& J. A. Wesson. 2000. Oyster reef restoration: convergence of harvest and conservation strategies. J. Shellfish Res. 19:371-377.

Burger, J. 2002. Effects of motorboats and personal watercraft on nesting terns: conflict resolution and the need for vigilance. In: M. J. Kennish, editor. Impacts of motorized watercraft on shallow estuarine and coastal marine environments. J. Coastal Res. (special issue). 37:7-17.

Carriker, M. R. \& P. M. Gaffney. 1996. A catalogue of selected species of 
living oysters (Ostreacea) of the world. In: V. S. Kennedy, R. I. E. Newell \& A. F. Eble, editors. The eastern oyster, Crassostrea virginica. Maryland Sea Grant College Program. College Park: University of Maryland. pp. 1-18.

Coen, L. D., D. M. Knott, E. L. Wenner, N. H. Hadley \& A. H. Ringwood. 1999a. Intertidal oyster reef studies in South Carolina: design, sampling and experimental focus for evaluating habitat value and function. In: M. W. Luckenbach, R. Mann, \& J. A. Wesson, editors. Oyster reef habitat restoration: a synopsis and synthesis of approaches. Gloucester Point, VA: Virginia Institute of Marine Science Press. pp. 133-158.

Coen, L. D., M. W. Luckenbach \& D. L. Breitburg. 1999b. The role of oyster reefs as essential fish habitat: a review of current knowledge and some new perspectives. In: L. R. Benaka, editor. Fish habitat: essential fish habitat and rehabilitation. American Fisheries Society, Symposium 22, Bethesda, MD. pp. 438-454.

Coen, L. D. \& M. W. Luckenbach. 2000. Developing success criteria and goals for evaluating oyster reef restoration: Ecological function or resource exploitation? Ecol. Eng. 15:323-343.

Crawford, R. E. 2002. Secondary wake turbidity from small boat operation in a shallow sandy bay. In: M. J. Kennish, editor. Impacts of motorized watercraft on shallow estuarine and coastal marine environments. J. Coastal Res. (Special Issue) 37:50-65.

Doty, M. S. 1971. Measurement of water movement in reference to benthic algal growth. Bot. Mar 14:32-35.

Dunton, K. H. \& S. V. Schonberg. 2002. Assessment of propeller scarring in seagrass beds of the south Texas coast. 2002. In: M. J. Kennish, editor. Impacts of motorized watercraft on shallow estuarine and coastal marine environments. J. Coastal Res. (Special Issue) 37:100110 .

Grizzle, R. E. 1990. Distribution and abundance of Crassostrea virginica (Gmelin, 1791) (eastern oyster) and Mercenaria spp. (quahogs) in a coastal lagoon. J. Shellfish Res. 9:347-358.

Grizzle, R. E. \& M. W. Castagna. 1995. Final Report-Oyster Reef Monitoring Program in Canaveral National Seashore, National Park Service, Titusville, FL. National Park Service, Canaveral National Seashore. $14 \mathrm{pp}$.

Grizzle, R. E., J. R. Adams \& L. J. Walters. 2002. Historical changes in intertidal oyster (Crassostrea virginica) reefs in a Florida lagoon potentially related to boating activities. J. Shellfish Res. 21:749-756.

Gunter, G. 1979. Studies of the southern oyster borer, Thais haemastoma. Gulf Res. Reports 6:249-260.

Hart, A. W., D. L. Meyers, T. M. O'Keefe \& M. G. Thorn. 1994. A boater's guide to the Indian River Lagoon. Melbourne, FL: National Estuary Program. 85 pp.

Harvey, K. 2004. 2003 Boating accident statistical report. Florida Fish and Wildlife Conservation Commission, Division of Law EnforcementBoating and Waterways Section. $68 \mathrm{pp}$.

Kennedy, V. S. 1996. Biology of larvae and spat. In: V. S. Kennedy, R. I. E. Newell \& A. F. Eble, editors. The eastern oyster, Crassostrea virginica. Maryland Sea Grant College Program, University of Maryland, College Park. pp. 371-422.

Kennish, M. J. 2002a. In: M. J. Kennish, editor. Impacts of motorized watercraft on shallow estuarine and coastal marine environments. $J$. Coastal Res. (special issue) 37:202.

Kennish, M. J. 2002b. Sediment contaminant concentrations in estuarine and coastal marine environments: potential for remobilization by boats and personal watercraft. Impacts of motorized watercraft on shallow estuarine and coastal marine environments. J. Coastal Res. (special issue). 37:151-178.

Kenworthy, W. D., M. S. Fonseca, P. E. Whitfield \& K. K. Hammerstrom. 2002. Impacts of motorized watercraft on shallow estuarine and coastal marine environments. J. Coastal Res. (special issue). 37:75-85.

Koch, E. W. 2002. Impact of boat-generated waves on a seagrass habitat. In: M. J. Kennish, editor. Impacts of motorized watercraft on shallow estuarine and coastal marine environments. J. Coastal Res. (special issue) $37: 66-74$
Konar, B. \& C. Roberts. 1996. Large-scale landslide effects on two exposed rocky subtidal areas. Bot. Mar. 39:517-524.

Lenihan, H. S. 1999. Physical-biological coupling on oyster reefs: how habitat structure influences individual performance. Ecol. Monogr. 69: 251-276.

Lenihan, H. S. \& C. H. Peterson. 1998. How habitat degradation through fishery disturbance enhances impacts of hypoxia on oyster reefs. Ecological applications through an estuarine feed web. Ecol. Appl. 8:128140.

Lenihan, H. S., F. Micheli, S. W. Shelton \& C. H. Peterson. 1999. The influence of multiple environmental stressors on susceptibility to parasites: an experimental determination with oysters. Limnol. Oceanogr. 44:210-224.

Levinton, J. S. 2001. Marine Biology. New York: Oxford University Press Inc. 515 pp.

Loya, Y. 1976. Effects of water turbidity and sedimentation on the community structure of Puerto Rico corals. Bull. Mar. Sci. 26:450-466.

Luckenbach, M. W., R. Mann \& J. A. Wesson. 1999. Oyster Reef Habitat Restoration: a synopsis and synthesis of approaches. Gloucester Point, VA: VIMS Press.

MacKenzie, C. L. 1977. Sea anemone predation on larval oysters in Chesapeake Bay (Maryland). Proceedings at the National Shellfish Association. 67:113-117.

MacKenzie, C. L. 1983. To increase oyster production in the northeastern United States. Mar. Fish. Rev. 45:1-22.

MacKenzie, C. L. 1996. Management of natural populations. In: V. S. Kennedy, R. I. E. Newell \& A. F. Ebele, editors. The Eastern Oyster, Crassostrea virginica. College Park, MD: Maryland Sea Grant. pp. 707-721.

Marshall, N. 1954. Changes in the physiolography of oyster bars in the James River, Virginia. VA Science New Series 5:173-181.

Morris, L. J., R. W. Virnstein, J. D. Miller \& L. M. Hall. 2000. Monitoring seagrass changes in the Indian River Lagoon, Florida, using fixed transects. In: S. A. Bortone, editor. Seagrassess: Monitoring, ecology, physiology, and management. Boca Raton, FL: CRC Press. pp. 167176.

Mullineaux, L. S. \& E. D. Garland. 1993. Larval recruitment in response to manipulated field flows. Mar. Biol. 116:667-683.

Muus, B. J. 1968. A field method for measuring "exposure" by means of plaster balls: a preliminary account. Sarsia 34:61-68.

Nelson, T. C. 1953. Some observations on the migrations and setting of oyster larvae. Proceedings of the National Shellfisheries Association. 43:99-104.

O'Beirn, F. X., P. B. Heffernan \& R. L. Walker. 1995. Preliminary recruitment studies of the eastern oyster, Crassostrea virginica. Aquaculture 136:231-242.

Ortega, S. \& J. P. Sutherland. 1992. Recruitment and growth of the eastern oyster, Crassostrea virginica, in North Carolina. Estuaries 15:158170.

Osman, R. W., R. B. Whitlach \& R. N. Zajac. 1989. Effect of resident species on recruitment into a community: larval settlement versus postsettlement mortality in the oyster Crassostrea virginica. Mar. Ecol. Prog. Ser. 54:61-73.

Perret, W. S., R. Dugas, J. Roussel, C. A. Wilson \& J. Supan. 1999. Oyster habitat restoration: a response to Hurricane Andrew. In: M. W. Luckenbach, R. Mann \& J. A. Wesson, editors. Oyster reef habitat restoration: a synopsis and synthesis of approaches. Gloucester Point, VA: Virginia Institute of Marine Science Press. pp 93-99.

Provancha, J. C., R. Hall \& D. M. Oddy. 1992. NASA Technical Memorandum 107548. $111 \mathrm{pp}$.

Sandford, E., D. Bermudez, M. D. Bertness \& S. D. Gaines. 1994. Flow, food supply, and acorn barnacle population dynamics. Mar. Ecol. Prog. Ser. 104:49-62.

Shumway, S. 1996. Natural environmental factors. In: V. S. Kennedy, R. I. E. Newell \& A. F. Ebel, editors. Maryland Sea Grant, College Park, MD. pp. 467-513. 
Tamburri, M. N., R. K. Zimmer-Faust \& M. L. Tamplin. 1992. Natural sources and properties of chemical inducers mediating settlement of oyster larvae: a re-examination. Biol. Bull. 83:327-338.

Tamburri, M. N., C. M. Finelli, D. S. Wethey \& R. K. Zimmer-Faust. 1996. Chemical induction of larval settlement behavior in flow. Biol. Bull. 191:367-373.

Thompson, T. L. \& P. Glenn. 1994. Plaster standards to measure water motion. Limnol. Oceanogr. 39:1768-1779.

Thompson, R. J., R. I. E. Newell, V. S. Kennedy \& R. Mann. 1996. Reproductive processes and early development. In: V. S. Kennedy, R. I. E. Newell \& A. F. Ebele, editors. Maryland Sea Grant, College Park, MD. pp. 335-370.

Turner, E. J., R. K. Zimmer-Faust, M. A. Palmer, M. Luckenbach \& N. D. Pentchef. 1994. Settlement of oyster (Crassostrea virginica) larvae: effects of water flow and a water-soluble chemical cue. Limnol. Oceanogr. 39:1579-1593.

Wall, L. M. 2004. Recruitment and restoration of the oyster Crassostrea virginica in areas with intense boating activity in Mosquito Lagoon, FL. M.S. Thesis. Orlando, FL: University of Central Florida. 70 pp.

Walters, L. J., A. Roman, J. Stiner \& D. Weeks. 2001. Water resource management plan, Canaveral National Seashore. Titusville, FL: National Park Service, Canaveral National Seashore. 224 pp.

Walters, L. J., K. Johnson, L. M. Wall, N. Martinez \& R. Grizzle. 2002. Shell movement and juvenile survival of the oyster Crassostrea virginica on intertidal reefs adjacent to waters with intense boating activity in the Indian River Lagoon, Florida. J. Shellfish Res. 21:415-416.

Whitfield, P. E., W. J. Kenworthy, K. K. Hammerstrom \& M. S. Fonseca. 2002. The role of a hurricane in the expansion of disturbances initiated by motor vessels on seagrass. In: M. J. Kennish, editor. Impacts of motorized watercraft on shallow estuarine and coastal marine environments. J. Coastal Res. (special issue) pp. 86-99.

Whitlatch, R. B. \& R. W. Osman. 1999. Oyster reefs as metapopulations: approaches for restoring and managing spatially fragmented habitats. In: M. W. Luckenbach, R. Mann \& J. A. Wesson, editors. Oyster reef habitat restoration: a synopsis and synthesis of approaches. Gloucester Point, VA: Virginia Institute of Marine Science Press. pp. 199-211.

Zimmer-Faust, R. K. \& M. N. Tamburri. 1994. Chemical identity and ecological implications of a waterborne, larval settlement cue. Limnol. Oceanogr. 39:1075-1087. 